\title{
Article \\ Chemical Vapor Deposition and Thermal Oxidation of Cuprous Phosphide Nanofilm
}

\author{
Xue Peng, Yanfei Lv and Shichao Zhao *D
}

check for

updates

Citation: Peng, X.; Lv, Y.; Zhao, S Chemical Vapor Deposition and Thermal Oxidation of Cuprous Phosphide Nanofilm. Coatings 2022, 12, 68. https://doi.org/10.3390/ coatings12010068

Academic Editors:

Torsten Brezesinski and

Alexandru Enesca

Received: 30 November 2021

Accepted: 5 January 2022

Published: 7 January 2022

Publisher's Note: MDPI stays neutral with regard to jurisdictional claims in published maps and institutional affiliations.

Copyright: (C) 2022 by the authors. Licensee MDPI, Basel, Switzerland. This article is an open access article distributed under the terms and conditions of the Creative Commons Attribution (CC BY) license (https:// creativecommons.org/licenses/by/ $4.0 /)$.
College of Materials and Environmental Engineering, Hangzhou Dianzi University, Hangzhou 310018, China; pengxue@hdu.edu.cn (X.P.); lvyanfei@hdu.edu.cn (Y.L.)

* Correspondence: zhaoshichao@hdu.edu.cn

\begin{abstract}
Inorganic semiconductors usually show n-type characterization; the development of p-type inorganic semiconductor material will provide more opportunities for novel devices. In this paper, we investigated the chemical vapor deposition $(\mathrm{CVD})$ of p-type cuprous phosphide $\left(\mathrm{Cu}_{3} \mathrm{P}\right)$ nanofilm and studied its thermal oxidation behavior. $\mathrm{Cu}_{3} \mathrm{P}$ film was characterized by optical microscopy, scanning electron microscopy (SEM), atomic force microscopy (AFM), laser Raman spectroscopy (Raman), and fluorescence spectroscopy (PL). We found that the thickness of film ranged from 4 to $10 \mathrm{~nm}$, and the film is unstable at temperatures higher than room temperature in air. We provide a way to prepare inorganic phosphide nanofilms. In addition, the possible thermal oxidation should be taken into consideration for practical application.
\end{abstract}

Keywords: cuprous phosphide; nanofilm; chemical vapor deposition; thermal oxidation

\section{Introduction}

Due to the intrinsic band structure and crystal defects, inorganic semiconductors usually exhibit natural n-type transporting property [1]; therefore, the development of a p-type inorganic semiconductor attracts considerable interest for the development of novel devices based on p-n junctions [2-4]. Copper compounds generally show ptype properties, such as cuprous oxide, cuprous sulfide and cuprous halide [5-7], and cuprous phosphide $\left(\mathrm{Cu}_{3} \mathrm{P}\right)$ is one of them. Cuprous phosphide is a p-type, narrow band gap semiconductor with an energy gap of about $1.6 \mathrm{eV}$ [8-11], which is of potential applications in light-emitting diodes, photodetectors, sensors and catalysis [12-18]. The morphologies of cuprous phosphide reported are usually thick film or nanosheets. For example, Pfeiffer et al. synthesized $\mathrm{Cu}_{3} \mathrm{P}$ particle film with a thickness of ca. $60 \mu \mathrm{m}$ through a solid reaction between copper and red phosphorous and discussed the growth mechanism $[19,20]$. Lee et al. reported the growth of $\mathrm{Cu}_{3} \mathrm{P}$ nanosheets with thickness ranging from $28 \mathrm{~nm}$ to $440 \mu \mathrm{m}$ by the reaction of copper foil and red phosphorous vapor [21]. $\mathrm{Mu}$ et al. used the solution method to obtain $\mathrm{Cu}_{3-\mathrm{x}} \mathrm{P}$ hexagonal nanocrystals with a lateral size of $20 \mathrm{~nm}$ and thickness of $2 \mathrm{~nm}$ [22]. The solution method generally produces particles. Nanofilm of $\mathrm{Cu}_{3} \mathrm{P}$ with thickness of several nanometers has not been reported. In this paper, we prepared $\mathrm{Cu}_{3} \mathrm{P}$ nanofilm by a chemical vapor deposition (CVD) method. The successful preparation $\mathrm{Cu}_{3} \mathrm{P}$ nanofilm is meaningful to study novel device-based p-n junctions.

Cuprous phosphide is generally considered stable in air [20], so is it really stable when the temperature is slightly higher than the room temperature? Therefore, we studied the thermal oxidation properties of $\mathrm{Cu}_{3} \mathrm{P}$. We found $\mathrm{Cu}_{3} \mathrm{P}$ is sensitive to the temperature. When temperature is higher than room temperature, $\mathrm{Cu}_{3} \mathrm{P}$ will be oxidized in the air, which should be taken into consideration during practical application. 


\section{Materials and Methods}

CVD growth of nanofilm. Nonofilm with a thickness of 4-10 nm was prepared on the silicon wafer with a native oxide layer. Sodium hypohosphite and copper foil were used as precursors. Sodium hypohosphite $(0.05 \mathrm{~mol})$ was placed in a corundum crucible covered with copper foil $(1 \mathrm{~cm} \times 1 \mathrm{~cm} \times 250 \mu \mathrm{m})$. They were placed in the centre of corundum tube, and heated to $800{ }^{\circ} \mathrm{C}$ with a rate of $10{ }^{\circ} \mathrm{C} / \mathrm{min}$ and kept at $800{ }^{\circ} \mathrm{C}$ for $2 \mathrm{~h}$. The silicon wafer was placed downstream of the tube. During the heating process of the precursor, the substrate was heated to ca. $700{ }^{\circ} \mathrm{C}$. After that, the tube was cooled to room temperature and flushed with argon to remove gaseous phosphide residues before the sample was taken out of the tube. Note that gaseous phosphide requires purification treatment. The edge of $\mathrm{Cu}_{3} \mathrm{P}$ nanofilm grown on the silicon substrate will form a step on the substrate, and the height of the step is equal to the thickness of the nanofilm. The step height was measured by atomic force microscopy.

Growth and annealing of thick film. To facilitate the study of thermal stability, $\mathrm{Cu}_{3} \mathrm{P}$ film with thickness of ca. $2.7 \mu \mathrm{m}$ was prepared by the reaction between copper foil and sodium hypophosphite according to the reference $[9,23,24]$. Sodium hypophosphite (Aladdin, Shanghai, China, 99.5\%, $0.05 \mathrm{~mol}$ ) was first placedin a corundum crucible covered with copper foil (Aladdin, Shanghai, China, 99.9\%) with a size of $1 \mathrm{~cm} \times 1 \mathrm{~cm} \times 250 \mu \mathrm{m}$. Then, they were put into a corundum tube and heated to $300{ }^{\circ} \mathrm{C}$ in argon for $2 \mathrm{~h}$ before cooled to room temperature. After cooling, the tube was flushed with argon to remove gaseous phosphide residues. Films were annealed at 50, 100, 200, 300 and $400{ }^{\circ} \mathrm{C}$, respectively, in air for 30 min to study thermal oxidation behaviour. The thickness of the $\mathrm{Cu}_{3} \mathrm{P}$ thick film was obtained by scanning the film cross section by scanning electron microscopy.

Optical microscope imaging was carried on a Jiangnan MV3000 digital microscope. Atomic force microscopy (AFM, tapping mode) was conducted on an Agilent 5500 (Agilent, Santa Clara, CA, USA). Scanning electron microscopy (SEM, Hitachi, Tokyo, Japan) was performed on Hitachi Su1510. Raman and photoluminescence spectra were carried on an HR Evo Nano (Horiba, Kyoto, Japan) with a $532 \mathrm{~nm}$ laser. The laser power was set at ca. $20 \mathrm{~mW} / \mathrm{mm}^{2}$. All the above measurements were carried out at room temperature.

\section{Results and Discussion}

Sodium hypophosphite decomposed at a high temperature to produce phosphine gas, which reacted with copper to form solid $\mathrm{Cu}_{3} \mathrm{P}$. Then, the solid $\mathrm{Cu}_{3} \mathrm{P}$ was vaporized and transported onto the surface of the cold substrate, where the deposition occurred. The substrate we used is a silicon single crystal wafer with a $300 \mathrm{~nm} \mathrm{SiO}$ layer. Due to the interference of visible light, nanofilm grown on such substrate can be observed through an optical microscope. Figure $1 \mathrm{a}$ is the optical image of $\mathrm{Cu}_{3} \mathrm{P}$, in which the area with purple color is corresponding to $\mathrm{Cu}_{3} \mathrm{P}$ film. From the optical image, we predict that the film is continuous. Some areas with cyan and grey colors are due to the thicker films or amorphous $\mathrm{Cu}_{3} \mathrm{P}$ deposited on the surface of the nanofilm. To further observe the details of the surface topography, we carried out the SEM. Figure $1 \mathrm{~b}$ is the SEM image the $\mathrm{Cu}_{3} \mathrm{P}$ nanofilm taken at the edge of the film, in which the area with light-color area is corresponding to the substrate, and dark-colored area is $\mathrm{Cu}_{3} \mathrm{P}$. We found that the $\mathrm{Cu}_{3} \mathrm{P}$ film is continuous. Many isolated $\mathrm{Cu}_{3} \mathrm{P}$ nanosheets were also observed at the edge of the continuous film. It is well known that the chemical potential of a small particle is larger than that of big one. Therefore, there is a trend that atoms will leave from the small particles to the continuous film, indicating that the growth is related to diffusion and growth processes. 

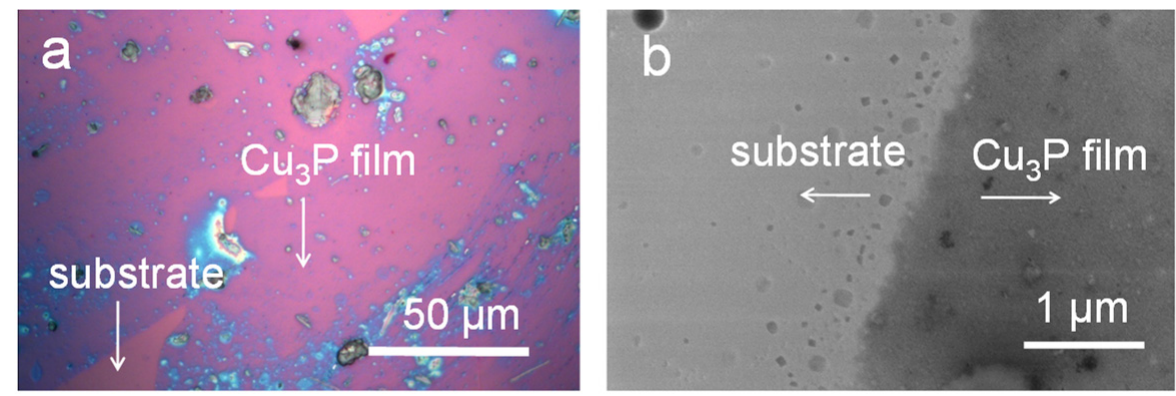

Figure 1. Typical optical microscope (a) and scanning electron microscope (b) images of the cuprous phosphide $\left(\mathrm{Cu}_{3} \mathrm{P}\right)$ nanofilm. The scale bars in $(\mathbf{a}, \mathbf{b})$ represent 50 and $1 \mu \mathrm{m}$, respectively.

The thickness and surface roughness were measured by AFM. Figure $2 \mathrm{a}, \mathrm{b}$ show the typical AFM images of $\mathrm{Cu}_{3} \mathrm{P}$ nanofilm taken at two different locations on the same sample. The thickness of the film is ranging from ca. 4 to ca. $7 \mathrm{~nm}$. The root-mean-square surface roughnesses of Figure $2 \mathrm{a}, \mathrm{b}$ are 0.26 and $0.28 \mathrm{~nm}$, respectively.
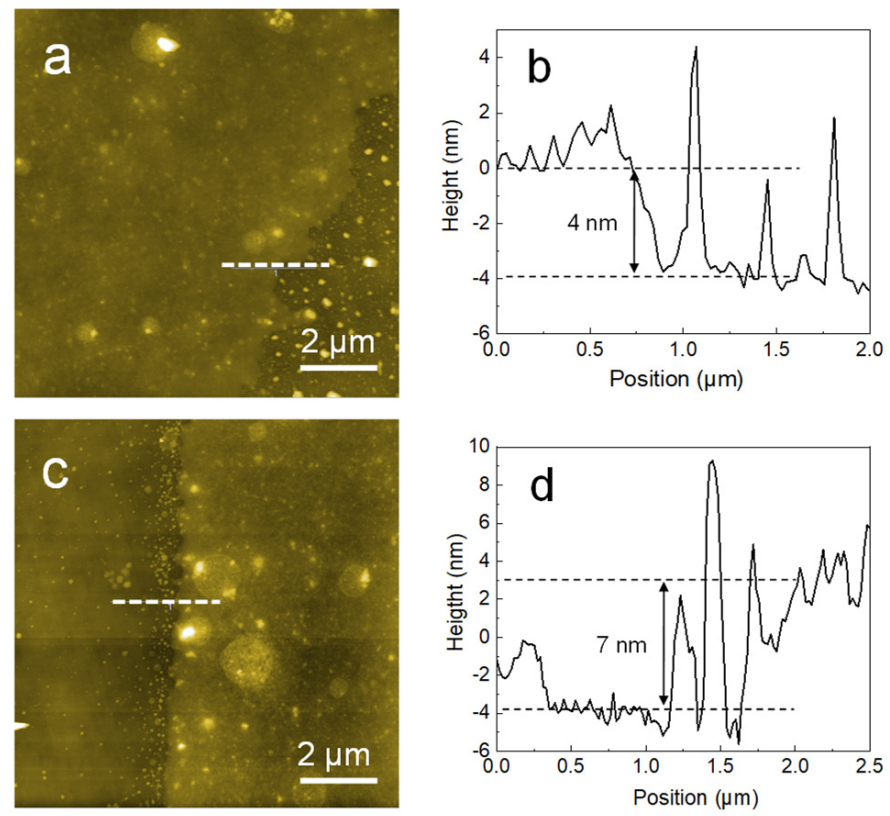

Figure 2. Typical atomic force microscopy (AFM) images (a,c) and corresponding cross section curves $(\mathbf{b}, \mathbf{d})$ of $\mathrm{Cu}_{3} \mathrm{P}$ nanofilm. The dark area is due to the silicon substrate. Scale bars in AFM images represent $2 \mu \mathrm{m}$.

Figure 3 shows the Raman spectra of the $\mathrm{Cu}_{3} \mathrm{P}$ nanofilm taken at different locations with different thicknesses. The peak at $524.5 \mathrm{~cm}^{-1}$ is corresponding to silicon $[25,26]$, which was used to calibrate the peak position. There are two peaks centred at 253 and $632 \mathrm{~cm}^{-1}$, which are due to $\mathrm{Cu}_{3} \mathrm{P}[9,27]$. The frequency difference between the two peaks is constant, unlike Van Der Waals two-dimensional materials, such as graphene, hexagonal boron nitride and molybdenum sulfide, of which the frequency difference is a function of the film thickness [28]. Therefore, the frequency difference cannot be utilized to determine the thickness of $\mathrm{Cu}_{3} \mathrm{P}$ film. The Raman peaks of bulk $\mathrm{Cu}_{3} \mathrm{P}$ are centered at 273 and $607 \mathrm{~cm}^{-1}$, respectively [9]. Compared with the bulk material, peak positions of $\mathrm{Cu}_{3} \mathrm{P}$ nanofilm shift and the frequency difference increases, which indicates the existence of the lattice defects and disorder $[29,30]$. 


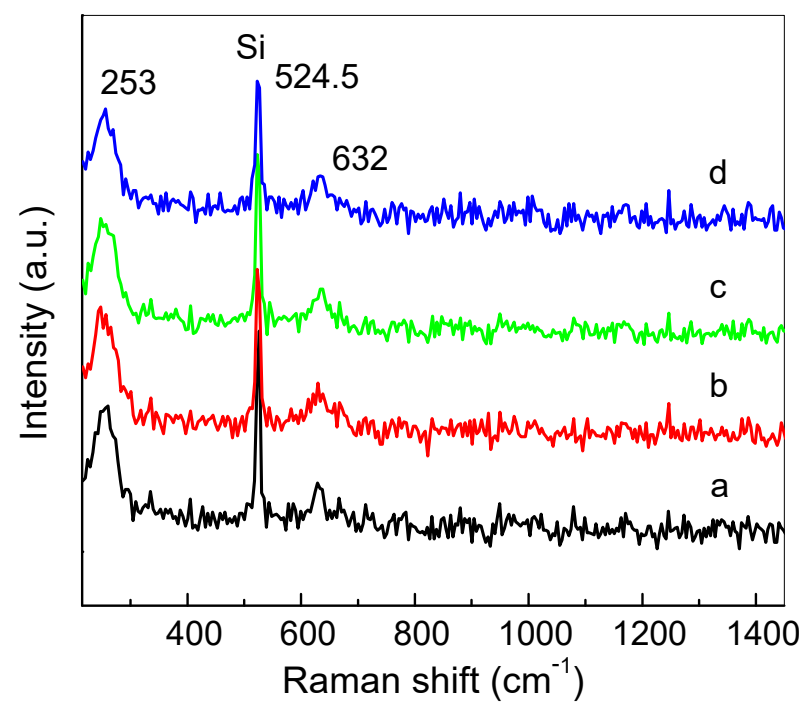

Figure 3. Raman spectra of $\mathrm{Cu}_{3} \mathrm{P}$ nanofilm taken at different locations with different thickness: (a) $10 \mathrm{~nm}$; (b) $7 \mathrm{~nm}$; (c) $5 \mathrm{~nm}$ and (d) $4 \mathrm{~nm}$, respectively.

Figure 4 show the photoluminescence spectra of $\mathrm{Cu}_{3} \mathrm{P}$ film with different thickness corresponding to the data in Figure 3. We observed a weak peak centered at ca. $700 \mathrm{~nm}$, which is possible due to the emission of $\mathrm{Cu}_{3} \mathrm{P}$ under the excitation of $532 \mathrm{~nm}$ laser. The weak photon emission indicates the $\mathrm{Cu}_{3} \mathrm{P}$ has a poor crystallinity. In addition, we found another broad-band emission ranging from ca. 555 to ca. $680 \mathrm{~nm}$. We had discussed the photoluminescence behavior of $\mathrm{Cu}_{3} \mathrm{P}$ in the presence of copper oxide in our previous work [9]. Cuprous phosphide is a direct band gap semiconductor with a band gap of ca. $1.5 \mathrm{eV}$. The photon energy of the broad-band emission is higher than the band gap of $\mathrm{Cu}_{3} \mathrm{P}$. Therefore, the broad-band emission is not due to $\mathrm{Cu}_{3} \mathrm{P}$, but copper oxides $[18,31,32]$. So where do these copper oxides come from? In this paper, copper reacted with the decomposition of sodium hyphosphite to form $\mathrm{Cu}_{3} \mathrm{P}$, and then $\mathrm{Cu}_{3} \mathrm{P}$ was evaporated and transported onto the surface of substrate, where the growth of $\mathrm{Cu}_{3} \mathrm{P}$ occurred. The growth took place in an inertatmosphere. The oxidation should not occur during this process. Szczuka et al. reported that diamond can be heated to $372 \mathrm{~K}$ by using a $532 \mathrm{~nm}$ laser with a power of $36 \mathrm{~mW} / \mathrm{mm}^{2}$ in $2 \mathrm{~min}$ [33]. Therefore, the possible reason is due to the laser irradiation during the photoluminescence characterization. The laser irradiation increased the temperature of $\mathrm{Cu}_{3} \mathrm{P}$. Then, $\mathrm{Cu}_{3} \mathrm{P}$ was oxidized by oxygen in the air. To test the hypothesis, we heated $\mathrm{Cu}_{3} \mathrm{P}$ using thick $\mathrm{Cu}_{3}$ Pfilm in air. To choose thick film instead of nanofilm for the thermal oxidation experiments, is considering the Raman signal of thick film is stronger than that of nanofilm. Figure 5 shows the Raman spectra of $\mathrm{Cu}_{3} \mathrm{P}$ thick film annealed at higher temperatures. Peaks of $\mathrm{Cu}_{3} \mathrm{P}$ could not be found in the samples annealed at 50 and $100{ }^{\circ} \mathrm{C}$. When the annealing temperature was increased above $200^{\circ} \mathrm{C}$, peaks of $\mathrm{Cu}_{2} \mathrm{O}\left(148,220\right.$, and $\left.512 \mathrm{~cm}^{-1}\right)$ and $\mathrm{CuO}\left(291\right.$ and $\left.636 \mathrm{~cm}^{-1}\right)$ were observed [34,35]. These results indicate that $\mathrm{Cu}_{3} \mathrm{P}$ undergo thermal oxidation at temperatures higher than room temperature. 


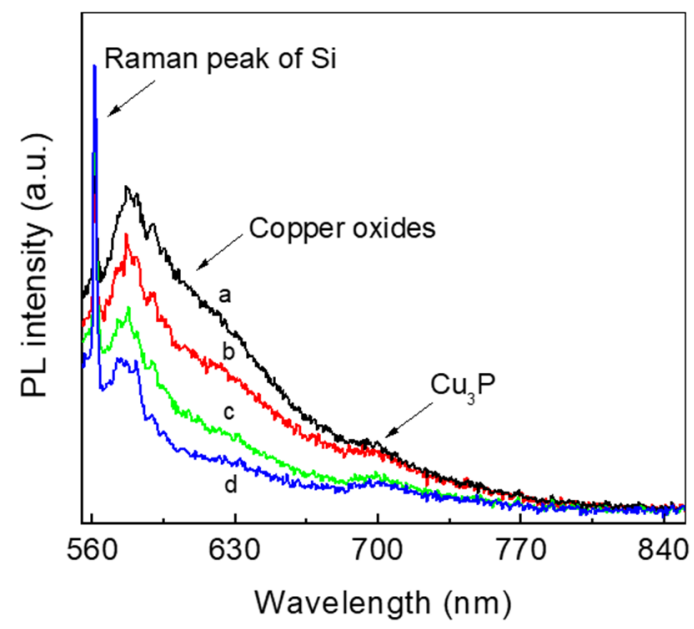

Figure 4. Photoluminescence spectra of $\mathrm{Cu}_{3} \mathrm{P}$ nanofilm with different thickness: (a) $10 \mathrm{~nm}$; (b) $7 \mathrm{~nm}$; (c) $5 \mathrm{~nm}$ and (d) $4 \mathrm{~nm}$, respectively.

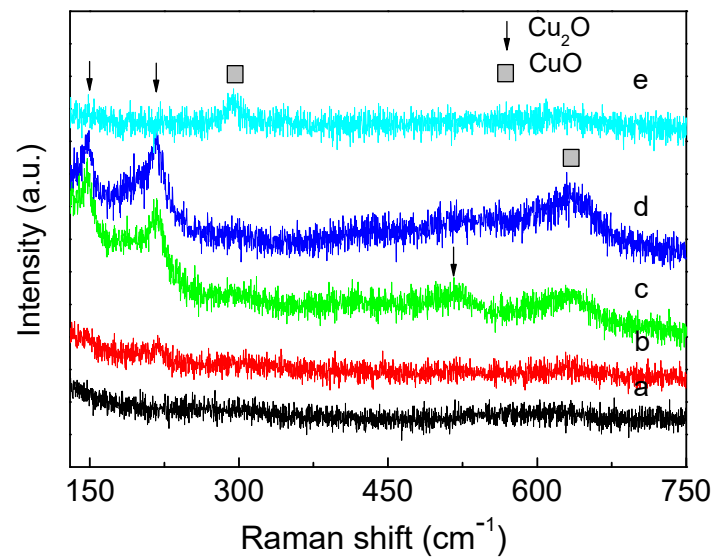

Figure 5. Raman spectra of $\mathrm{Cu}_{3} \mathrm{P}$ films annealed at different temperatures: (a) $50{ }^{\circ} \mathrm{C}$; (b) $100{ }^{\circ} \mathrm{C}$; (c) $200{ }^{\circ} \mathrm{C}$; (d) $300{ }^{\circ} \mathrm{C}$ and (e) $400{ }^{\circ} \mathrm{C}$, respectively.

\section{Conclusions}

In this paper, we prepared cuprous phosphide nanofilm through the chemical vapor deposition method. We found the Raman peaks of the $\mathrm{Cu}_{3} \mathrm{P}$ nanofilm is independent on the film thicknessand the photoluminescence emission of the nanofilm is weak. In addition, we found the presence of copper oxides in PL and Raman spectra when the film was exposed to the laser irradiation or heated in air. Our study showed that $\mathrm{Cu}_{3}$ Pnano film was unstable at temperatures higher than room temperature in air.

Author Contributions: S.Z. and Y.L. conceived and designed the experiments and wrote the paper, X.P. performed the experiments and wrote the paper. All authors have read and agreed to the published version of the manuscript.

Funding: This research received no external funding.

Institutional Review Board Statement: Not applicable.

Informed Consent Statement: Not applicable.

Data Availability Statement: Data sharing is not applicable to this article.

Conflicts of Interest: The authors declare no conflict of interest. 


\section{References}

1. Liu, A.; Zhu, H.H.; Noh, Y.Y. Solution-processed inorganic p-channel transistors: Recent advances and perspectives. Mat. Sci. Eng. R Rep. 2019, 135, 85-100. [CrossRef]

2. Teng, F.; Hu, K.; Ouyang, W.X.; Fang, X.S. Photoelectric detectors based on inorganic p-type semiconductor materials. Adv. Mater. 2018, 30, 1706262. [CrossRef] [PubMed]

3. Kim, T.; Jeong, J.K. Recent progress and perspectives of field-effect transistors based on p-type oxide semiconductors. Phys. Status Solidi R 2021, 2100394. [CrossRef]

4. Zhang, P.; Yu, S.; Zhang, X.W.; Wei, S.H. Design of p-type transparent conductors from inverted band structure: The case of inorganic metal halide perovskites. Phys. Rev. Mater. 2019, 3, 055201. [CrossRef]

5. Jayathilaka, K.M.D.C.; Kapaklis, V.; Siripala, W.; Jayanetti, J.K.D.S. Ammonium sulfide surface treatment of electrodeposited p-type cuprous oxide thin films. Electron. Mater. Lett. 2014, 10, 379-382. [CrossRef]

6. Parreira, P.; Lavareda, G.; Valente, J.; Nunes, F.T.; Amaral, A.; de Carvalho, C.N. Optoelectronic properties of transparent p-type semiconductor CuxS thin films. Phys. Status Solidi A 2010, 207, 1652-1654. [CrossRef]

7. Yamada, N.; Ino, R.; Tomura, H.; Kondo, Y.; Ninomiya, Y. High-mobility transparent p-type CuI semiconducting layers fabricated on flexible plastic sheets: Toward flexibletransparent electronics. Adv. Electron. Mater. 2017, 3, 1700298. [CrossRef]

8. Sheets, E.J.; Yang, W.C.; Balow, R.B.; Wang, Y.; Walker, B.C.; Stach, E.A.; Agrawal, R. An in situ phosphorus source for the synthesis of $\mathrm{Cu}_{3} \mathrm{P}$ and the subsequent conversion to $\mathrm{Cu}_{3} \mathrm{PS}_{4}$ nanoparticle clusters. J. Mater. Res. 2015, 30, 3710-3716. [CrossRef]

9. $\quad$ Peng, X.; Lv, Y.F.; Fu, L.; Chen, F.; Su, W.T.; Li, J.Z.; Zhang, Q.; Zhao, S.C. Photoluminescence properties of cuprous phosphide prepared through phosphating copper with a native oxide layer. RSC Adv. 2021, 11, 34095-34100. [CrossRef]

10. Fu, Z.Y.; Ma, X.Y.; Xia, B.; Hu, X.Y.; Fan, J.; Liu, E.Z. Efficient photocatalytic $\mathrm{H}_{2}$ evolution over $\mathrm{Cu}_{\text {and }} \mathrm{Cu}_{3} \mathrm{P}$ co-modified TiO ${ }_{2}$ nanosheet. Int. J. Hydrogen Energy 2021, 46, 19373-19384. [CrossRef]

11. Gaspari, R.; Labat, F.; Manna, L.; Adamo, C.; Cavalli, A. Semiconducting and optical properties of selected binary compounds by linear response DFT plus U and hybrid functional methods. Theor. Chem. Acc. 2016, 135, 73. [CrossRef]

12. Li, H.; Jia, C.; Meng, X.W.; Li, H.B. Chemical synthesis and applications of colloidal metal phosphide nanocrystals. Front. Chem. 2019, 6, 652. [CrossRef]

13. Kuwano, T.; Katsube, R.; Nose, Y. Improvement of ohmic behavior of back contact in $\mathrm{ZnSnP}_{2}$ solar cells by inserting $\mathrm{Cu}_{3} \mathrm{P}$. In Proceedings of the 2019 IEEE 46th Photovoltaic Specialists Conference PVSC, Chicago, IL, USA, 16-21 June 2019; pp. 3007-3009.

14. Zhu, S.; Wang, J.; He, Y.; Yu, Z.; Wang, X.; Su, W. In situ photodeposition of amorphous NixP on CdS nanorods for efficient visible-light photocatalytic $\mathrm{H}_{2}$ generation. Catal. Sci. Technol. 2019, 9, 5394-5400. [CrossRef]

15. Tappan, B.A.; Chen, K.; Lu, H.; Sharada, S.M.; Brutchey, R.L. Synthesis and electrocatalytic HER studies of carbene-ligated $\mathrm{Cu}_{3-\mathrm{x}}$ P nanocrystals. ACS Appl. Mater. Interf. 2020, 12, 16394-16401. [CrossRef]

16. Zhang, X.; Yan, J.; Lee, L.Y.S. Highly promoted hydrogen production enabled by interfacial P N chemical bonds in copper phosphosulfide Z-scheme composite. Appl. Catal. B 2021, 283, 119624. [CrossRef]

17. Wolff, A.; Doert, T.; Hunger, J.; Kaiser, M.; Pallmann, J.; Reinhold, R.; Yogendra, S.; Giebeler, L.; Sichelschmidt, J.; Schnelle, W.; et al. Low-temperature tailoring of copper-deficient $\mathrm{Cu}_{3-\mathrm{x}} \mathrm{P}$-electric properties, phase transitions, and performance in lithium-ion batteries. Chem. Mater. 2018, 30, 7111-7123. [CrossRef]

18. Hua, S.; Qu, D.; An, L.; Jiang, W.; Wen, Y.; Wang, X.; Sun, Z. Highly efficient p-type $\mathrm{Cu}_{3} \mathrm{P} / \mathrm{n}$-type g- $\mathrm{C}_{3} \mathrm{~N}_{4}$ photocatalyst through Z-scheme charge transfer route. Appl. Catal. B 2019, 240, 253-261. [CrossRef]

19. Pfeiffer, H.; Tancret, F.; Brousse, T. Synthesis, characterization and electrochemical properties of copper phosphide $\left(\mathrm{Cu}_{3} \mathrm{P}\right)$ thick films prepared by solid-state reaction at low temperature: A probable anode for lithium ion batteries. Electrochim. Acta 2005, 50, 4763-4770. [CrossRef]

20. Pfeiffer, H.; Tancret, F.; Bichat, M.P.; Monconduit, L.; Favier, F.; Brousse, T. Air stable copper phosphide $\left(\mathrm{Cu}_{3} \mathrm{P}\right)$ : A possible negative electrode material for lithium batteries. Electrochem. Commun. 2004, 6, 263-267. [CrossRef]

21. Lee, S.W.; Kim, J.; Woo, S.G.; Park, Y.; Yoon, J.C.; Park, H.J.; Kim, N.Y.; Shin, H.S.; Lee, Z. Epitaxially grown copper phosphide $\left(\mathrm{Cu}_{3} \mathrm{P}\right)$ nanosheets nanoarchitecture compared with film morphology for energy applications. Surf. Interf. 2021, 26, 101369. [CrossRef]

22. Mu, H.; Liu, Z.; Bao, X.; Wan, Z.; Liu, G.; Li, X.; Shao, H.; Xing, G.; Shabbir, B.; Li, L.; et al. Highly stable and repeatable femtosecond soliton pulse generation from saturable absorbers based on two-dimensional $\mathrm{Cu}_{3-x} \mathrm{P}$ nanocrystals. Front. Optoelectron. 2020, 13, 139-148. [CrossRef]

23. Pawar, S.M.; Pawar, B.S.; Babar, P.T.; Ahmed, A.T.A.; Chavan, H.S.; Jo, Y.; Cho, S.; Kim, J.; Inamdar, A.I.; Kim, J.H.; et al. Electrosynthesis of copper phosphide thin films for efficient water oxidation. Mater. Lett. 2019, 241, 243-247. [CrossRef]

24. Hao, J.H.; Yang, W.S.; Huang, Z.P.; Zhang, C. Superhydrophilic and superaerophobic copper phosphide microsheets for efficient electrocatalytic hydrogen and oxygen evolution. Adv. Mater. Interf. 2016, 3, 1600236. [CrossRef]

25. Yoo, W.S.; Harima, H.; Yoshimoto, M. Polarized Raman signals from Si wafers: Dependence of in-plane incident orientation of probing light. ECS J. Solid State Sci. Technol. 2015, 4, 356-363. [CrossRef]

26. Poborchii, V.; Tada, T.; Morita, Y.; Kanayama, T.; Geshev, P.I. High near-ultraviolet Raman efficiency of silicon nanowires with small cross sections. Phys. Rev. B 2011, 83, 153412. [CrossRef]

27. Liu, S.L.; He, X.D.; Zhu, J.P.; Xu, L.Q.; Tong, J.B. $\mathrm{Cu}_{3} \mathrm{P} / \mathrm{RGO}$ Nanocomposite as a new anode for lithium-ion batteries. Sci. Rep. 2016, 6, 35189. [CrossRef] [PubMed] 
28. Xu, Z.H.; Lv, Y.F.; Li, J.Z.; Huang, F.; Nie, P.B.; Zhang, S.W.; Zhao, S.C.; Zhao, S.X.; We, G.D. CVDcontrolled growth of large-scale $\mathrm{WS}_{2}$ monolayers. RSC Adv. 2019, 9, 29628. [CrossRef]

29. Jovanovic, S.; Krasic, M.S. Asymmetric defects in one-dimensional photonic lattices. Laser Phys. 2021, 31, 023001. [CrossRef]

30. Fedele, F.; Yang, J.K.; Chen, Z.G. Defect modes in one-dimensional photonic lattices. Opt. Lett. 2005, 30, 1506-1508. [CrossRef]

31. Wu, T.; Zheng, H.; Kou, Y.C.; Su, X.Y.; Kadasala, N.R.; Gao, M.; Chen, L.; Han, D.L.; Liu, Y.; Yang, J.H. Self-sustainable and recyclable ternary $\mathrm{Au} @ \mathrm{Cu}_{2} \mathrm{O}-\mathrm{Ag}$ nanocomposites: Application in ultrasensitive SERS detection and highly efficient photocatalysis of organic dyes under visible light. Microsyst. Nanoeng. 2021, 7, 1-10. [CrossRef]

32. Singh, J.; Juneja, S.; Soni, R.K.; Bhattacharya, J. Sunlight mediated enhanced photocatalytic activity of $\mathrm{TiO}_{2}$ nanoparticles functionalized $\mathrm{CuO}-\mathrm{Cu}_{2} \mathrm{O}$ nanorods for removal of methylene blue and oxytetracycline hydrochloride. J. Colloid Interf. Sci. 2021, 590, 60-71. [CrossRef] [PubMed]

33. Szczuka, C.; Drake, M.; Reimer, J.A. Effects of laser-induced heating on nitrogen-vacancy centers and single-nitrogen defects in diamond. J. Phys. D Appl. Phys. 2017, 50, 395307. [CrossRef]

34. Houng, B.; Wu, J.K.; Yeh, P.C.; Yeh, W.L.; Sun, C.K. Effect of $\mathrm{Cu}$ addition on the properties of the RF magnetron-sputtered $\mathrm{Cu}_{2} \mathrm{O}$ thin films. J. Electroceram. 2020, 45, 129-134. [CrossRef]

35. Dubale, A.A.; Pan, C.J.; Tamirat, A.G.; Chen, H.M.; Su, W.N.; Chen, C.H.; Rick, J.; Ayele, D.W.; Aragaw, B.A.; Lee, J.F.; et al. Heterostructured $\mathrm{Cu}_{2} \mathrm{O} / \mathrm{CuO}$ decorated with nickel as a highly efficient photocathode for photoelectrochemical water reduction. J. Mater. Chem. A 2015, 3, 12482-12499. [CrossRef] 